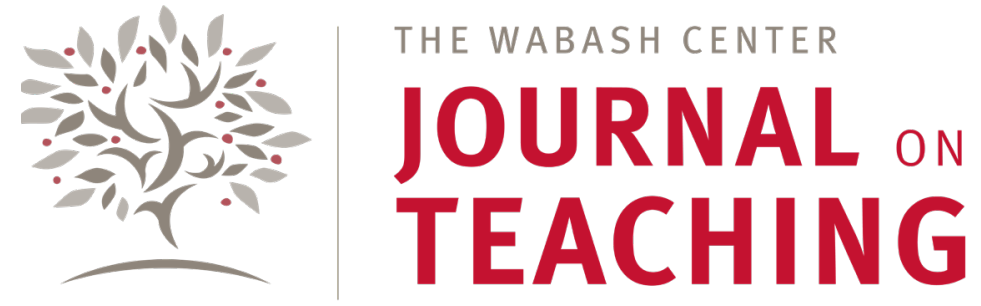

F O R U M

\title{
Creating Our Better Selves: The Fruits of Katie Cannon's Womanist Pedagogy
}

\author{
Karen K. Seat \\ The University of Arizona
}

\begin{abstract}
Katie Geneva Cannon equipped generations of students with analytical tools to reckon with the past and present and to creatively construct previously unimaginable futures. Her body of work teaches us to find new paths as we critically plumb our own historically situated epistemologies and put them in conversation with a variety of traditions. As my teacher, dissertation advisor, and mentor during my graduate studies in religion at Temple University from 1993-2000, Dr. Cannon taught me to examine rigorously my own story in its larger historical and geopolitical contexts, to parse the privileges and perils of pursuing the academic study of religion as a white woman, and to engage deeply with multitudinous ways of knowing. See companion contributions to this Forum written by Edwin David Aponte, Miguel A. De La Torre, Stacey M. Floyd-Thomas, and Angela D. Sims.
\end{abstract}

\section{KEYWORDS}

Katie Cannon, pedagogy, womanism, womanist

I want to discuss how institutionalized domination in the past bears on the present, so that women of color in contemporary classrooms, and all who cast their lot with us, can move from what is to what can be.... [I]n this globalized age of multiculturalism, we already know by way of successful experiences that a generation of students has benefited from pluralistic and participatory education.

- Katie G. Cannon $(2016,115,119)$

Katie Geneva Cannon's life and legacy stand as a call to grapple with the injustices of the past and present while creatively constructing previously unimaginable futures. Her body of work teaches us to find new paths as we critically plumb our own historically situated epistemologies and put them in conversation with a variety of traditions. As a mentor to generations of scholars situated both inside and outside the womanist movement, she reminded us to "stay mindful that there is no unitary essence of human being-ness" $(2018,131)$. Dr. Cannon's womanist pedagogy helps us to attend to the particularities of our own stories, so that we can better comprehend innumerable sources of wisdom, as well as sites of oppression to which we may have been blinded - and to which we may have contributed - that begin to emerge for us more clearly when we do not universalize our own perspectives and assumptions.

Dr. Cannon was my teacher, dissertation advisor, and mentor during my graduate studies in religion at Temple University from 1993-2000. Starting a PhD program in Philadelphia at age twenty-three, after growing up in Japan as the child of Southern 
Baptist missionaries and then graduating from a Baptist-affiliated college in Missouri, I learned from Dr. Cannon to examine rigorously my own story in its larger historical and geopolitical contexts, to parse the privileges and perils of pursuing the academic study of religion as a white woman, and to engage deeply with the multitudinous ways of knowing different from my own. Participating in Dr. Cannon's graduate courses as a student, and in her undergraduate classrooms as one of her teaching assistants, I was steeped in the groundbreaking pedagogy of this premier womanist scholar and educator. I was fortunate to be one of the many students whose life was transformed by this extraordinary teacher, who knew how to equip us with tools for the critical, intersectional analysis needed to reckon with the past and present and to pursue "what can be."

Katie Cannon's womanist pedagogy is invaluable for any educator committed to empowering students to become "self-conscious and deliberate learners" $(2014,325)$. Although I am not a theologian or a womanist myself, my more than twenty years of teaching religious studies to university students has been informed by Dr. Cannon's womanist pedagogy. I continue to be inspired by the profound respect she had for each and every student. She actively demonstrated this in the classroom and beyond, coaching students through face-to-face and written interactions to examine their own points of resonance and dissonance with course materials. Her dedication to her students was unparalleled; her approach to teaching involved hours of "reading students' papers the way letters are read, to learn more, especially more about the person," while "conducting a running dialogue in the margins of each paper, informing students of supplemental readings and challenging them to find their ethical voice" $(2014,325)$. She transformed the classroom into what today we might call a "safe space," but what she would more profoundly and accurately describe as a "nonalienating experience," carefully "designed to facilitate students in teaching themselves what they need to know" - including the courageous pursuit of knowledge that can be disorienting and even frightening at times $(2014,326,323)$.

Dr. Cannon's womanist pedagogy has shaped my goals as an educator, as I seek to facilitate students' abilities to historically contextualize all knowledge, and to critically examine the power dynamics at play when placing religion in its historical and political contexts. Students become invested in this process through historically situating their own heritages. One of Dr. Cannon's assignments that I use to this day is the Socio-Religious Autobiography, in which students write an essay unpacking their own religious/ethnic/cultural histories while exploring how these heritages are connected to larger historical dynamics. As I tell my students, to read the socio-religious autobiographies submitted in a large course at a public university is to learn with each essay ever more about the human experience around the globe. Each person in the classroom is a part of the human story we are examining through the academic study of religions across geography and time.

In Dr. Cannon's womanist pedagogy, assignments are simultaneously personally meaningful and academically rigorous. In addition to learning critical thinking tools through the elaboration of their own personal narratives, students are challenged to investigate historical documents, literature, sacred texts, and various media assigned throughout the course to determine "whose experience is validated, what groups are left out, what ideology accompanies the analysis, and what is the framework that provides meaning and holds conflicting elements together" $(2014,325)$. Students come to understand not only that the personal is the political and the historical, but that all matters involving human beings are embedded in powerful webs of meaning, thick with tensions.

Dr. Cannon's womanist praxis was focused and expansive. She gave priority to African American women, "placing Black women's experiences, perspectives, and realities at the center of the discourse, rather than at the margins" $(2018,120)$. Those who, as she put it, "cast their lot with us," learned to take inventory of their own positionality when engaging with womanism, by "actively seeking and naming the cognitive dissonance they experience in their belief systems, lifestyles, and behavior" (2014, 325). In doing so, we continually create our better selves.

\section{BIBLIOGRAPHY}

Cannon, Katie G. 2014. "Pedagogical Praxis in African American Theology." In The Oxford Handbook of African American Theology, edited by Katie G. Cannon and Anthony Pinn, 319-330. New York, NY: Oxford University Press.

Cannon, Katie G. 2016. “Eliminating Ignorance.” Journal of Feminist Studies in Religion 32, no. 1: 114-120.

Cannon, Katie G. 2018. “Womanist Mentoring - African American Perspectives.” In Mentoring: Biblical, Theological, and Practical Perspectives, edited by Dean K. Thompson and D. Cameron Murchison. Grand Rapids, MI: William B. Eerdmans. 


\section{ADDITIONAL CONTRIBUTORS TO THIS FORUM HONORING DR. KATIE GENEVA CANNON}

Aponte, Edwin David. 2020. "Reflections on the Pedagogy of My Professor and Mentor Katie Geneva Cannon." The Wabash Center Journal on Teaching 1(1): 107-110. https://doi.org/10.31046/wabashjournal.v1i1.1589.

De La Torre, Miguel A. 2020. “Personalizing Katie’s Canon.” The Wabash Center Journal on Teaching 1(1): 97-99. https://doi.org/10.31046/wabashjournal.v1i1.1587.

Floyd-Thomas, Stacey M. 2020. “Teaching the Canon and Cannon Formation as Incarnation and Conjure: Dr. Katie Geneva Cannon as Womanist Mentor and Muse.” The Wabash Center Journal on Teaching 1(1): 87-91. https://doi.org/10.31046/ wabashjournal.v1i1.1585.

Sims, Angela D. 2020. "Deep Breaths and High Impact Aerobics: Reflecting on Teaching Writing in the Key of Katie Geneva Cannon." The Wabash Center Journal on Teaching 1(1): 101-105. https://doi.org/10.31046/wabashjournal.v1i1.1588.

\section{ABOUT THE AUTHOR}

Karen K. Seat is associate professor of religious studies at the University of Arizona, where she serves as the head of the Department of Religious Studies \& Classics and the director of the School of International Languages, Literatures, and Cultures (SILLC). She specializes in U.S. religious history, American evangelicalism, and gender studies. 
